\title{
Soil Washing Technology for Removing Heavy Metals from a Contaminated Soil: A Case Study
}

\author{
Khalid A. Alaboudi ${ }^{1,2 *}$, Berhan Ahmed ${ }^{1}$, Graham Brodie ${ }^{3}$ \\ ${ }^{1}$ Ecosystem and Forest Science, University of Melbourne, Australia \\ ${ }^{2}$ National Center of Biotechnology Information, King Abdulaziz City for Science and Technology, Saudi Arabia \\ ${ }^{3}$ Faculty of Veterinary and Agricultural Sciences, Dookie Campus, University of Melbourne, Australia
}

Received: 25 November 2018

Accepted: 23 February 2019

\begin{abstract}
Although EDTA solution is considered an efficient soil washing liquid for extraction of heavy metals from soils, its low biodegradability may alter soil properties and suppress plant growth. Alternatively, chlorides are safer and cheaper washing liquids than EDTA. To investigate the efficiency of chlorides versus EDTA in extracting heavy metals from contaminated soils, soil samples ( $\mathrm{pH}$ 6.14 \pm 0.11 ) were collected from a local agriculture soil in Australia, artificially contaminated with either $\mathrm{Pb}, \mathrm{Cd}$ or $\mathrm{Cr}$ at three different levels of 200, 400 and $600 \mathrm{mg} \mathrm{kg}^{-1}$, and then packed in capped plastic flasks. Batch washing techniques were followed with either EDTA or $\mathrm{FeCl}_{3}$ solutions (prepared at 4 different concentrations of $0.05,0.1,0.25$ and $0.5 \mathrm{M}$ ), and soil suspensions were agitated for different time periods (from $5.0 \mathrm{~min}$. to $60.0 \mathrm{~min}$ ); afterward, the extraction efficiencies of the investigated metals were considered. The removal efficiency of $\mathrm{Pb}$ from the contaminated soil $\left(200 \mathrm{mg} \mathrm{Pb} \mathrm{kg} \mathrm{p}^{-1}\right)$ after 5 minutes of EDTA application seemed to be relatively high $(\approx 75 \%)$. Afterward this efficiency decreased gradually with time. The efficiencies of the extracted $\mathrm{Cd}$ and $\mathrm{Cr}$ by soil washing with EDTA increased significantly with increases in the agitating period. Generally, the extraction efficiencies by EDTA decreased noticeably with increasing levels of soil contamination. On the other hand, the efficiencies of $\mathrm{Pb}, \mathrm{Cd}$ and $\mathrm{Cr}$ extractions were high - especially when increasing both the concentrations of applied $\mathrm{FeCl}_{3}$ solution and the time of agitation. The results also highlighted that soil washing with $\mathrm{FeCl}_{3}$ seemed to be more favourable over EDTA for rapid extraction of heavy metals from contaminated soils. The efficiencies of extracting heavy metals by soil washing with $0.5 \mathrm{M} \mathrm{FeCl}$ for only one hour were $93.79 \pm 2.35 \%, 97.4 \pm 2.45 \%$ and $81.75 \pm 7.86 \%$ for $\mathrm{Pb}, \mathrm{Cd}$ and $\mathrm{Cr}$, respectively.
\end{abstract}

Keywords: heavy metals, soil, EDTA, $\mathrm{FeCl}_{3}$, soil washing

*e-mail: alaboudi@student.unimelb.edu.au 


\section{Introduction}

Soil pollution is an important issue worldwide [1] - especially when related to heavy metals [2]. These metals are not biodegradable and can persist in soils for years [3]. Soil is considered the main sink of these metals [4] and the presence of heavy metals can impose serious health hazards for human life, animals and aquatic biota with prolonged exposure [5-7]. Thus, soil remediation is necessary to attain more acceptable environmental conditions [8]. In this concern, ethylene di amine tetra acetic acid (EDTA) forms water-soluble complexes with heavy metals in soil $[9,10]$ and therefore is considered an efficient soil-washing liquid for extracting these metals from soils $[11,12]$. This amendment can also be used for inducing phytoextraction of heavy metals [13] and probably metalloids from polluted soils by grown plants [14]. However, EDTA is of low biodegradability in soil [12] and persists under natural conditions [15]. Up to $64 \%$ of applied EDTA can be retained in an acidic soil after remediation [16]. Such conditions may alter soil properties and suppress plant growth [17].

Alternatively, chlorides are safer and cheaper washing liquids than EDTA [18]. These chlorides are used successfully in extracting heavy metals from soil $[19,20]$. It is worth mentioning that the complexation process of EDTA with heavy metals is endothermic and spontaneous [21], inducing 2-step processes (i.e., fast desorption within the first hour followed by steady release within subsequent hours) [22]. Thus, there is a need to investigate the efficiency of chlorides versus EDTA to extract heavy metals from contaminated soils - especially within the first 60-minute time period after application. To attain this aim, soil samples $(\mathrm{pH}$ $6.14 \pm 0.06)$ were collected and artificially contaminated with the following metals of $\mathrm{Pb}, \mathrm{Cd}$ and $\mathrm{Cr}$ at three different levels (i.e., 200, 400 and $600 \mathrm{mg} \mathrm{kg}^{-1}$ ). These samples were packed in capped plastic flasks. Batch washing experiments were followed using either EDTA or $\mathrm{FeCl}_{3}$ solutions (prepared at 4 different concentrations). The soil suspensions were agitated for different time periods (from $5.0 \mathrm{~min}$. to 60.0 min); afterward, heavy metal concentrations were measured in the supernatants and the extraction efficiencies of heavy metals were considered, and the major changes ( $\mathrm{pH}, \mathrm{EC}$ and organic matter contents) that might occurred in soil were also a matter of concern.

\section{Materials and Methods}

\section{Soil Sampling and Preparation}

Surface soil samples (0-30 cm depth) were collected from Burnley Campus Garden at Melbourne University, Australia. The collected soil samples were air dried, ground and passed through a $2 \mathrm{~mm}$ sieve to remove debris and stones. The prepared soil samples were
Table 1. Physical and chemical properties of the studied soil.

\begin{tabular}{|c|c|c|}
\hline Parameter & Unit & Value \\
\hline $\mathrm{pH}$ & -- & $6.14 \pm 0.11$ \\
\hline $\mathrm{EC}$ & $\mathrm{dS} \mathrm{m}^{-1}$ & $0.27 \pm 0.02$ \\
\hline O.M. & $\%$ & $10.23 \pm 0.74$ \\
\hline Total $\mathrm{Pb}$ & $\mathrm{mg} \mathrm{kg}^{-1}$ & $26.3 \pm 3.8$ \\
\hline Total $\mathrm{Cd}$ & $\mathrm{mg} \mathrm{kg}^{-1}$ & $1.11 \pm 0.32$ \\
\hline Total Cr & $\mathrm{mg} \mathrm{kg}^{-1}$ & $9.47 \pm 032$ \\
\hline \multicolumn{3}{|c|}{ Particle size distribution } \\
\hline Sand & $\%$ & 81.00 \\
\hline Silt & $\%$ & 12.80 \\
\hline Clay & $\%$ & 6.20 \\
\hline Textural class & \multicolumn{2}{|c}{ Loamy sand } \\
\hline
\end{tabular}

analysed for their physical and chemical properties (Table 1).

\section{Preparing Pb-, Cd- and Cr-Contaminated Soil}

A clean soil (1000 g) was placed in a $5000 \mathrm{~mL}$ highdensity polyethylene container, and then the very fine salts of $\mathrm{PbO}, \mathrm{CdCO}_{3}$ and $\mathrm{Cr}_{2} \mathrm{O}_{3}$ were mixed with the soil to bring the concentrations of studied metals to 200 , 400 and $600 \mathrm{mg} \mathrm{kg}^{-1}$ for each. In this study we aimed to use less soluble salts to investigate the efficiency of selected washing solutions to remove $\mathrm{Pb}, \mathrm{Cd}$ and $\mathrm{Cr}$ from contaminated soils. For $200 \mathrm{mg} \mathrm{kg}^{-1}$ artificially contaminated soil, $0.22 \mathrm{~g}$ of $\mathrm{PbO}, 0.31 \mathrm{~g}$ of $\mathrm{CdCO}_{3}$, and $0.29 \mathrm{~g}$ of $\mathrm{Cr}_{2} \mathrm{O}_{3}$ was mixed with the soil. In addition, $0.43 \mathrm{~g}$ of $\mathrm{PbO}, 0.63 \mathrm{~g}$ of $\mathrm{CdCO}_{3}, 2.92 \mathrm{~g}$ of $\mathrm{Cr}_{2} \mathrm{O}_{3}$ and $0.59 \mathrm{~g}$ of $\mathrm{Cr}_{2} \mathrm{O}_{3}$ was added to $1 \mathrm{~kg}$ of soil to get the soil to $400 \mathrm{mg} \mathrm{kg}^{-1}$ of each element. For the $600 \mathrm{mg} \mathrm{kg}^{-1}$ artificially contaminated soil, $0.65 \mathrm{~g}$ of $\mathrm{PbO}, 0.94 \mathrm{~g}$ of $\mathrm{CdCO}_{3}$, and $0.88 \mathrm{~g}$ of $\mathrm{Cr}_{2} \mathrm{O}_{3}$ was mixed with $1 \mathrm{~kg}$ of soil. The prepared soils were irrigated to field capacity and incubated for one month to ensure that the added metal ions were distributed homogeneously throughout the soil. After the incubation period, the soil samples were air dried and subjected to further experimental procedures.

\section{Preparation of Washing Solutions}

Washing solutions of iron chloride $\left(\mathrm{FeCl}_{3}, 97 \%\right)$ and ethylene di amine tetra acetic acid- di potassium (purity 98\%) salts with different concentrations of 0.0 , $0.05,0.10,0.25$ and $0.5 \mathrm{M}$ were prepared by dissolving $0.0,8.36,16.72,43.10$ and $88.90 \mathrm{~g}$ of $\mathrm{FeCl}_{3}$ in a litter of deionized water to attain the above-mentioned concentrations, respectively. In addition, 20.64, 41.27, 105.28 and $210.56 \mathrm{~g}$ of EDTA-di potassium salt were dissolved in $1 \mathrm{~L}$ in order to attain the concentrations of $0.0,0.05,0.10,0.25$ and $0.5 \mathrm{M}$, respectively. 


\section{Batch Washing Studies}

Batch washing experiments were conducted using a series of capped plastic flasks of $100 \mathrm{~mL}$ capacity on a mechanical shaker. The effects of initial soil concentration and shaking time on the removal of heavy metals were investigated. The concentrations of $\mathrm{Pb}, \mathrm{Cd}$ and $\mathrm{Cr}$ were 0.0, 200, 400 and $600 \mathrm{mg} \mathrm{kg}^{-1}$ soil. Time course experiments were carried out by shaking the sorption mixture at various agitation times from $5.0 \mathrm{~min}$. to $60.0 \mathrm{~min}$. (5.0, 15, 30 and $60 \mathrm{~min}$.). All experiments were carried out at an agitation rate of $180 \mathrm{rpm}$. At the end of the agitation time, the supernatant was separated from soil particles by centrifuging at $5000 \mathrm{rpm}$ for $10 \mathrm{~min}$. and analysed for their contents of $\mathrm{Pb}, \mathrm{Cd}$ and Crby using inductively coupled plasma (ICP; Jobin Yvon Horiba - ULTIMA 2, France) supplemented with a hydride generator system.

\section{Soil Analysis}

The collected soil samples were subjected to several analyses prior to and after soil washing procedures. Soil reaction $(\mathrm{pH})$ and electrical conductivity (EC) were determined in 1:1 soil-to-water suspensions and supernatant, respectively [23]. Organic matter was determined using loss on ignition method [24]. In addition, total contents of $\mathrm{Pb}, \mathrm{Cd}$ and $\mathrm{Cr}$ were measured in the soil samples following digestion by aqua regia [25].

\section{Statistical Analysis}

All results were statistically analyzed using the SAS package (ver. 9.1). Means of three replicates for all chemicals and physical analyses were subjected to oneway ANOVA. Tukey's honestly significant difference (HSD) studentized range test was applied for significant differences among means $(\mathrm{P}<0.05)$. The graphs were plotted using the Sigma Plot 10 program. Extraction efficiency of studied metals was calculated as follows:

$$
\text { Extraction efficiency }(\%)=
$$

Amount of heavy metals in supernatuant amounts of initial heavy metal +total added of heavy metals $* 100$

\section{Results and Discussion}

\section{Extraction of $\mathrm{Pb}$ from the Contaminated Soil}

Fig. 1 shows the extraction efficiency of $\mathrm{Pb}$ from soil using distilled water, EDTA and $\mathrm{FeCl}_{3}$ solutions. Clearly
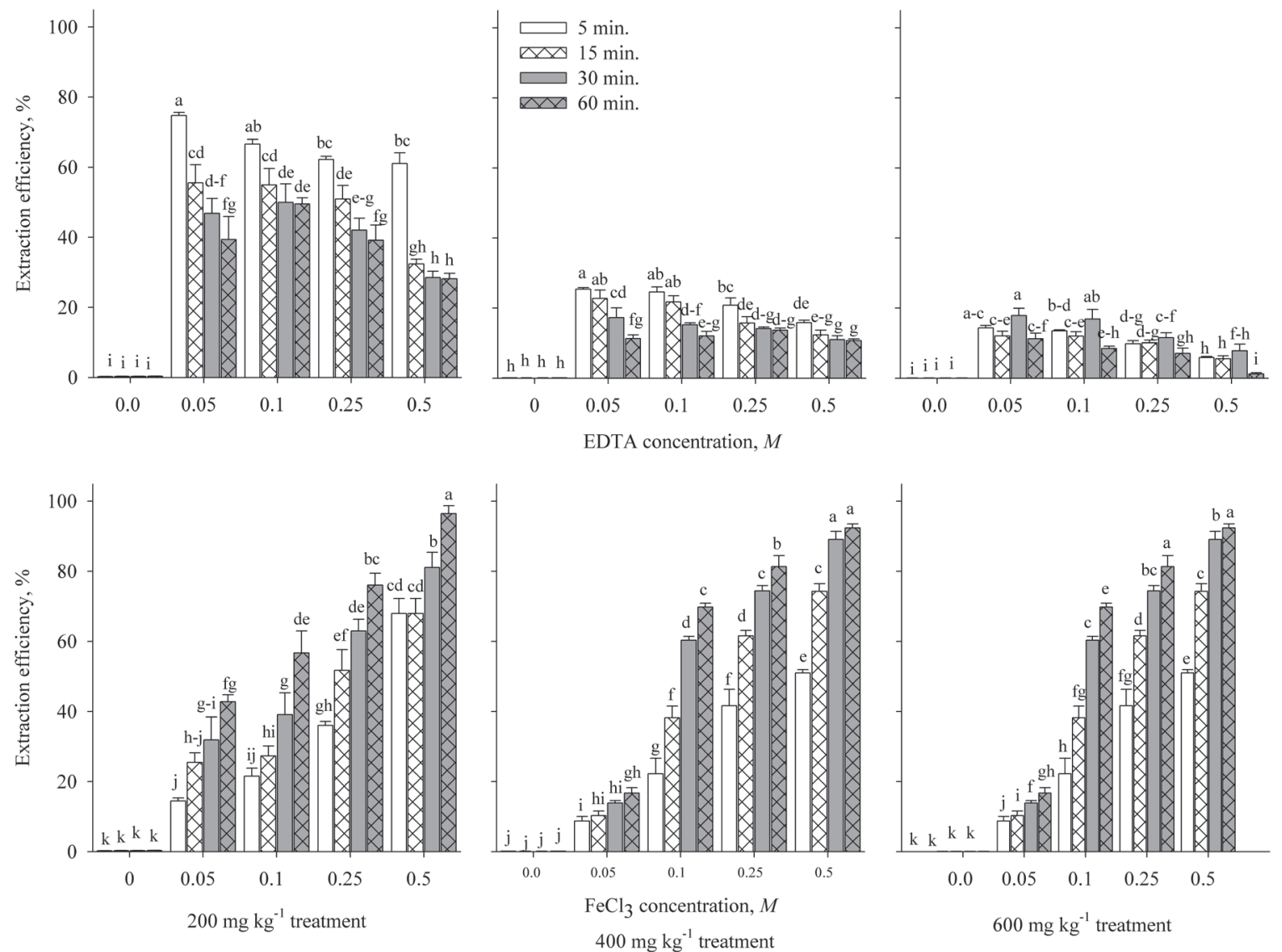

Fig. 1. Extraction of $\mathrm{Pb}$ from soil $\left(200,400\right.$ and $\left.600 \mathrm{mg} \mathrm{kg}^{-1}\right)$ with different concentrations of EDTA and $\mathrm{FeCl}_{3}$ extracts $(0.05,0.1,0.25$ and $0.5 \mathrm{M})$ at different shaking time $(5.0,15,30$ and $60 \mathrm{~min}$.). Means with the same letter within columns are not significantly different. 
either EDTA or $\mathrm{FeCl}_{3}$ solutions have the ability to extract $\mathrm{Pb}$ compared to distilled water. The removal efficiency of $\mathrm{Pb}$ from the contaminated soil $\left(200 \mathrm{mg} \mathrm{Pb} \mathrm{kg}^{-1}\right)$ after 5 minutes of EDTA application seemed to be relatively high $(\approx 75 \%)$; afterward, this efficiency decreased gradually with time (Fig. 1). On the other hand, the $\mathrm{Pb}$-extraction efficiency decreased noticeably with the increasing level of soil contamination with $\mathrm{Pb}$ (added in the form of $\mathrm{PbO}$ ), in spite of that, no significant effect was detected for increasing the concentrations of EDTA solution on the calculated $\mathrm{Pb}$-extraction efficiencies. Generally, the solubility of $\mathrm{PbO}$ in soil depends on its $\mathrm{pH}$ value [26] and can be considered according to the reaction suggested by Lindsay [27] as follows:

$$
\mathrm{PbO}+2 \mathrm{H}^{+} \leftrightarrow \mathrm{Pb}^{2+}+\mathrm{H}_{2} \mathrm{O}
$$

This reaction probably increased soil $\mathrm{pH}$ and this might, in turn, increase $\mathrm{Pb}$ sorption by dimer silicate and/or aluminum groups [28]. Accordingly, the mobility and bioavailability of $\mathrm{Pb}$ in soils decreased [29]. Although the application of EDTA to soil is thought to form soluble $\mathrm{Pb}$-complexes [12, 30], under such alkaline conditions, the efficiency of heavy metal extraction with EDTA seemed to be relatively low [22] and probably formed $\mathrm{Pb}$-EDTA complexes of relatively low mobility [31].

Alternatively, the application of $\mathrm{FeCl}_{3}$ to the investigated soil might be an appropriate solution to increase the efficiency of $\mathrm{Pb}$ extracted from soils. Results obtained herein reveal that the efficiency of $\mathrm{Pb}$ removal increased significantly with increasing concentrations of applied $\mathrm{FeCl}_{3}$ solution. Such increases seemed to be more pronounced with increasing contact time up to $60 \mathrm{~min}$ (Fig. 1). It seems that the efficiency of $\mathrm{Pb}$ extraction from the contaminated soils by $\mathrm{FeCl}_{3}$ did not vary significantly when increasing the level of $\mathrm{Pb}$ contamination in soil. This might take place because of the acidic action of $\mathrm{FeCl}_{3}$ in soil as illustrated from the equations adapted from Lindsay [27]. The soil $\mathrm{pH}$ gradually decreased from 6.14 in the control treatment to reach 1.96 when the soil was treated with $0.5 \mathrm{M}$ of $\mathrm{FeCl}_{3}$ (Table 2)

$$
\begin{gathered}
\mathrm{FeCl}_{3} \leftrightarrow \mathrm{Fe}^{3+}+3 \mathrm{Cl}^{-} \\
\mathrm{Fe}^{3+}+3 \mathrm{H}_{2} \mathrm{O} \leftrightarrow \mathrm{Fe}(\mathrm{OH})_{3}^{0}+3 \mathrm{H}^{+}
\end{gathered}
$$

Thus, the solubility and bio-availability of heavy metals (i.e., $\mathrm{Pb}$ ) in such acidic conditions increased [32]. It is worth mentioning that the superiority of $\mathrm{FeCl}_{3}$ solution over EDTA in extracting Pb from soil was also noticed by Guo et al. [20].

\section{Extraction of Cd from Artificially Contaminated Soils}

Fig. 2 reveals that washing the contaminated soil with either EDTA or $\mathrm{FeCl}_{3}$ solution significantly improved the efficiency of the extracted $\mathrm{Cd}$ from soil. Moreover, increasing the concentrations of the washing solution resulted in further significant increases in the Cd-extraction efficiency. However, distilled water recorded the lowest extraction efficiency of $\mathrm{Cd}$ compared to EDTA and $\mathrm{FeCl}_{3}$ solutions. The reaction time was an additional significant factor affecting the $\mathrm{Cd}$ extraction efficiencies. This might be attributed to the effectiveness of the metal binding organic ligand (EDTA) in chelating Cd [33] to form soluble [34] and bioavailable complexes [35]. Accordingly, EDTA is an effective means for remediating soils contaminated with $\mathrm{Cd}[36,37]$.

On the other hand, soils that were washed with $\mathrm{FeCl}_{3}$ extracts might form soluble metal (Cd)-chloride complexes [38] and these soluble complexes probably increased the removal percentage of $\mathrm{Cd}$ from soil [39] - especially at low soil pH. Generally, these two

Table 2. Changes of soil properties as affected by EDTA and $\mathrm{FeCl}_{3}$ washing solutions.

\begin{tabular}{|c|c|c|c|c|}
\hline Washing solution & Concentration, $\mathrm{M}$ & $\mathrm{pH}$ & $\mathrm{EC}, \mathrm{ds} \mathrm{m}{ }^{-1}$ & O.M., $\%$ \\
\hline \multirow{4}{*}{ EDTA } & Control & $6.14 \pm 0.06 \mathrm{a}$ & $0.27 \pm 0.013 \mathrm{~d}$ & $10.23 \pm 0.74 \mathrm{c}$ \\
\cline { 2 - 5 } & 0.05 & $6.15 \pm 0.03 \mathrm{a}$ & $0.83 \pm 0.05 \mathrm{~d}$ & $11.05 \pm 0.07 \mathrm{bc}$ \\
\cline { 2 - 5 } & 0.1 & $6.16 \pm 0.03 \mathrm{a}$ & $1.62 \pm 0.22 \mathrm{c}$ & $11.47 \pm 0.06 \mathrm{~b}$ \\
\cline { 2 - 5 } & 0.25 & $6.10 \pm 0.1 \mathrm{a}$ & $4.22 \pm 0.41 \mathrm{~b}$ & $12.82 \pm 0.11 \mathrm{a}$ \\
\cline { 2 - 5 } & 0.5 & $6.2 \pm 0.06 \mathrm{a}$ & $7.34 \pm 0.14 \mathrm{a}$ & $13.37 \pm 0.13 \mathrm{a}$ \\
\hline \multirow{3}{*}{$\mathrm{FeCl}_{3}$} & Control & $6.14 \pm 0.06 \mathrm{a}$ & $0.27 \pm 0.013 \mathrm{e}$ & $10.23 \pm 0.74 \mathrm{a}$ \\
\cline { 2 - 5 } & 0.05 & $4.19 \pm 0.08 \mathrm{~b}$ & $0.53 \pm 0.1 \mathrm{~d}$ & $10.24 \pm 0.16 \mathrm{a}$ \\
\cline { 2 - 5 } & 0.1 & $3.28 \pm 0.08 \mathrm{c}$ & $0.89 \pm 0.02 \mathrm{c}$ & $10.45 \pm 0.32 \mathrm{a}$ \\
\cline { 2 - 5 } & 0.25 & $2.8 \pm 0.1 \mathrm{~d}$ & $1.94 \pm 0.07 \mathrm{~b}$ & $10.42 \pm 0.08 \mathrm{a}$ \\
\hline
\end{tabular}

Means with the same letter within column are not significantly different. 

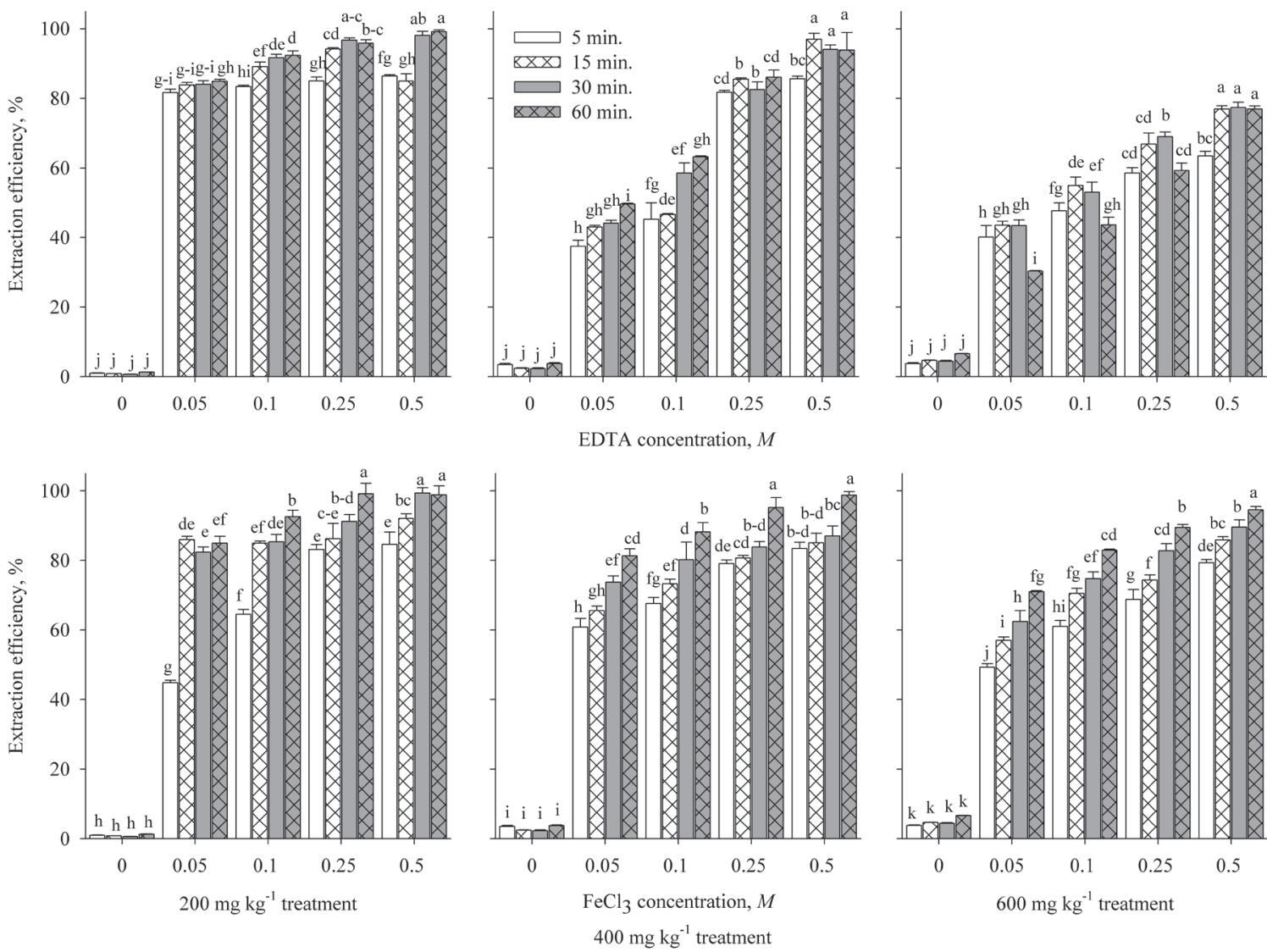

Fig. 2. Extraction of Cd from soil (200, 400 and $\left.600 \mathrm{mg} \mathrm{kg}^{-1}\right)$ with different concentrations of EDTA and $\mathrm{FeCl}_{3}$ extracts $(0.05,0.1,0.25$ and $0.5 \mathrm{M})$ at different shaking time $(5.0,15,30$ and $60 \mathrm{~min}$.). Means with the same letter within columns are not significantly different.

amendments seemed to have comparable effects on increasing the extraction efficiency of $\mathrm{Cd}$ from lower contaminated soil, i.e., $200 \mathrm{mg} \mathrm{Cd} \mathrm{kg}^{-1}$. However, $\mathrm{FeCl}_{3}$ seemed to be more favorable over EDTA for washing Cd-contaminated soil when the level of soil contamination is $400 \mathrm{mg} \mathrm{Cd} \mathrm{kg}^{-1}$ or higher.

\section{Extraction of $\mathrm{Cr}$ from Artificially Contaminated Soils}

Results reveal that soil washing with either EDTA or $\mathrm{FeCl}_{3}$ solution resulted in significant increases in the extraction efficiency of $\mathrm{Cr}$ from the soil compared to distilled water (Fig. 3). The concentration of either of these extracts was of further significant effect on the extraction process of $\mathrm{Cr}$ from contaminated soil. In this concern, $\mathrm{FeCl}_{3}$ seemed to be more efficient than EDTA in the extraction process of $\mathrm{Cr}$ from soil throughout the investigated reaction time periods. Generally, information available on extraction of $\mathrm{Cr}$ from soils with EDTA is limited. This information refers to the potentiality of EDTA in decontaminating soils polluted with $\mathrm{Cr}[40,41]$. However, the removal efficiency of $\mathrm{Cr}$ from soils seems to be low compared with the other metals because $\mathrm{Cr}$ exists mainly in the form of bichromate $\left(\mathrm{HCrO}_{4}^{-}\right)$anion [42]. The results obtained herein also reveal that the time of contact was of significant effect on Cr-extraction efficiency by EDTA. It seems that the 60-minute time period was probably enough to attain successful extraction of $\mathrm{Cr}$ (extraction efficiency $\approx 90 \%$ ) from the contaminated soil (i.e., $200 \mathrm{mg} \mathrm{Cr} \mathrm{kg}^{-1}$ ) after being washed with $0.5 \mathrm{M}$ EDTA extract. The corresponding efficiencies decreased in soils of higher contamination levels (i.e., 400 and $600 \mathrm{mg} \mathrm{Cr} \mathrm{kg}{ }^{-1}$ ). It is worth mentioning that only a 30-minute time period was enough to attain successful soil washing with EDTA in soil contaminated with $600 \mathrm{mg} \mathrm{Cr} \mathrm{kg}{ }^{-1}$. Concerning the soil washing with $\mathrm{FeCl}_{3}$, results show that increasing the concentration of $\mathrm{FeCl}_{3}$ solution resulted in corresponding significant increases in Cr-extraction efficiency. The strong acidic conditions that were provided during the hydrolysis of $\mathrm{FeCl}_{3}[18]$ might enhance the reduction of $\mathrm{Cr}(\mathrm{IV})$ to form soluble Cr(III) [43].

\section{Changes in Soil properties Caused by Soil Washing}

Data presented in Table 2 show the major changes occurring in the treated soil neither by EDTA nor $\mathrm{FeCl}_{3}$ extracts. The obtained results showed that EDTA has no significant effect on soil $\mathrm{pH}$. The value of soil $\mathrm{pH}$ varied from 6.10 to 6.16. However, using $\mathrm{FeCl}_{3}$ extract led to a significant reduction in soil $\mathrm{pH}$ in order to reach 

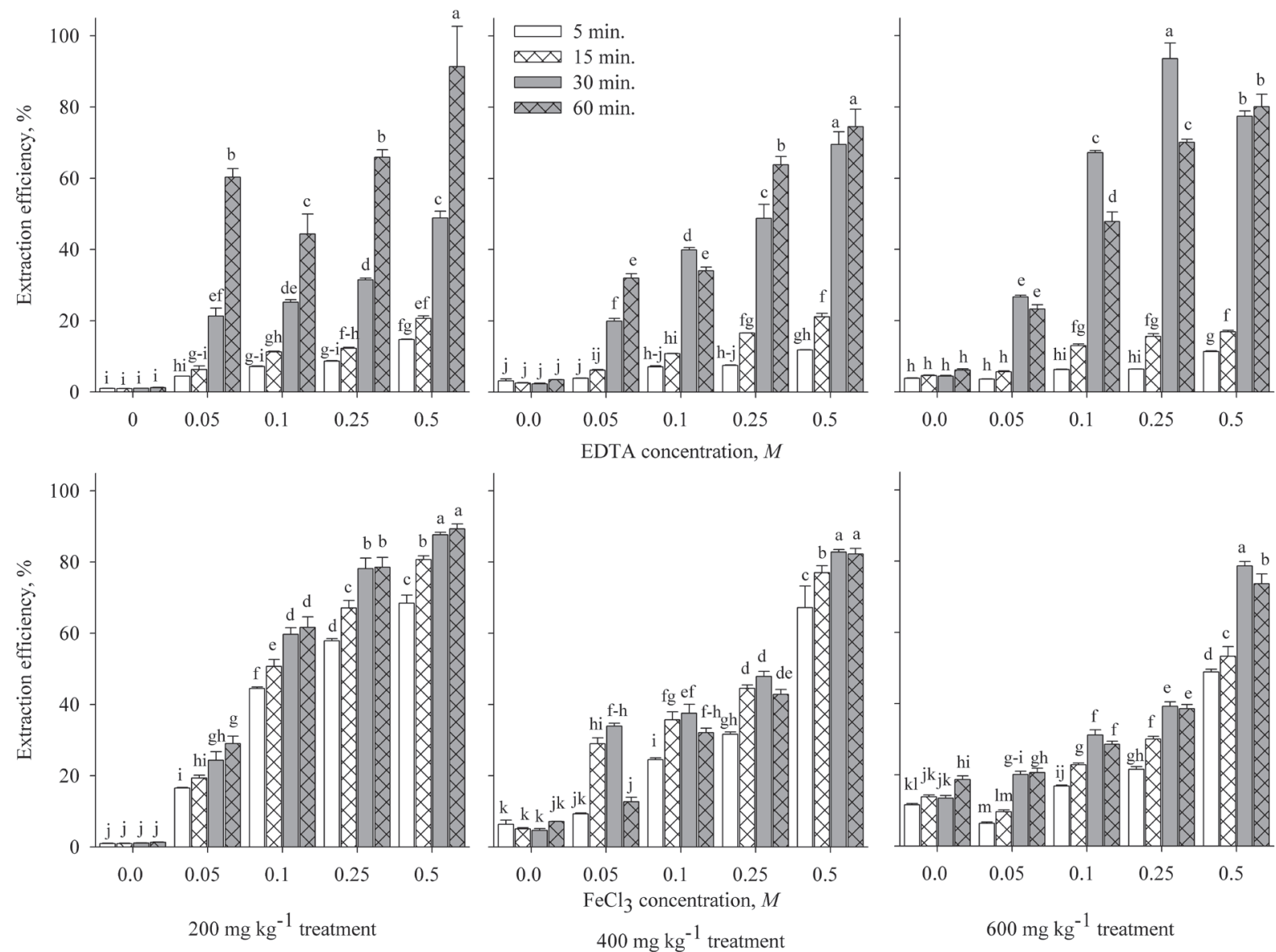

Fig. 3. Extraction of $\mathrm{Cr}$ from soil $\left(200,400\right.$ and $\left.600 \mathrm{mg} \mathrm{kg}^{-1}\right)$ with different concentrations of EDTA and $\mathrm{FeCl}_{3}$ extracts $(0.05,0.1,0.25$ and $0.5 \mathrm{M})$ at different shaking time $(5.0,15,30$ and $60 \mathrm{~min})$. Means with the same letter within columns are not significantly different.

the lowest value of 1.96 when the soil was treated with $0.5 \mathrm{M}$ of $\mathrm{FeCl}_{3}$ extract. It is clear that increasing the concentration of $\mathrm{FeCl}_{3}$ gradually decreased the soil $\mathrm{pH}$ due to the hydrolysis of $\mathrm{FeCl}_{3}$.

On the other hand, EDTA has no significant effect on soil $\mathrm{pH}$. However, increasing the concentration of EDTA washing solution gradually increased soil EC value compared to $\mathrm{FeCl}_{3}$ washing solution. The EC value of the treated soil with EDTA was almost two times those of $\mathrm{FeCl}_{3}$ treatments. The highest $\mathrm{EC}$ value was recorded for EDTA treatment with an average value of $7.34 \mathrm{dS}$ $\mathrm{m}^{-1}$ when the soil was treated with $0.5 \mathrm{M}$ of EDTA. A positive action was observed for EDTA washing solution, by increasing the concentration of EDTA treatment organic matter contents of the treated soils was increased. The values of organic matter contents were $10.23,11.05,11.47,12.82$ and $13.37 \%$ when the soil was washed by EDTA washing solution of $0.0,0.05,0.1$, 0.25 and $0.5 \mathrm{M}$ solutions, respectively. The increase of soil organic matter could be attributed to the presence of organic carbon in EDTA compound [14]. $\mathrm{FeCl}_{3}$ has no significant effect on soil organic matter contents. From the above-mentioned information, attention should be paid when using soil washing technology for treating heavy metal-contaminated soils to avoid the leachability of macro nutrients (i.e., N, P and K).
In addition, the increased soil salinity might hinder the agricultural productivity of the treated soil. Therefore, additional treatments might be required to leach the soil to overcome the salinization problem.

\section{Conclusions}

In conclusion, soil washing with $\mathrm{FeCl}_{3}$ seemed to be more favourable over EDTA for rapid extraction of heavy metals from contaminated soils. The efficiencies of extracting heavy metals by soil washing with $0.5 \mathrm{M}$ $\mathrm{FeCl}_{3}$ for only one hour were $93.79 \pm 2.35 \%$ for $\mathrm{Pb}$, $97.4 \pm 2.45 \%$ for $\mathrm{Cd}$ and $81.75 \pm 7.86 \%$ for Cr. Attention should be paid regarding the use of EDTA and $\mathrm{FeCl}_{3}$ washing solutions regarding the potential leachability of soil macro nutrients (i.e., N, P and K), and the potential salinization of soil when treated with washing solutions - especially EDTA.

\section{Acknowledgments}

The authors would like to express their thanks to the reviewers who reviewed this manuscript. 


\section{Conflict of Interest}

The authors declare no conflicts of interest.

\section{References}

1. CHEN M., XU P., ZENG G., YANG C., HUANG D., ZHANG J. Bioremediation of soils contaminated with polycyclic aromatic hydrocarbons, petroleum, pesticides, chlorophenols and heavy metals by composting: Applications, microbes and future research needs. Biotechnol Adv. 33, 745, 2015. https://doi.org/10.1016/j. biotechadv.2015.05.003.

2. ABDELHAFEZ A.A., LI J. Environmental monitoring of heavy metal status and human health risk assessment in the agricultural soils of the Jinxi River area, China. Hum Ecol Risk Assess. 21(4), 952, 2015. https://doi.org/10.1080/ 10807039.2014.947851

3. ADRIANO D.C. Trace Elements in Terrestrial Environments: Biogeochemistry, Bioavailability and Risks of Metals, Springer, $2^{\text {nd }}$ edition, New York, NY, USA. 2003.

4. ASRARI E. Heavy Metal Contamination of Water and Soil: Analysis, Assessment, and Remediation Strategies, 1st edition, Apple Academic Press, New York. 2014.

5. ABDELHAFEZ A.A., ABBAS M.H.H., ATTIA T.M.S. Environmental monitoring of heavy-metals status and human health risk assessment in the soil of Sahl ElHessania area, Egypt. Pol J Environ Stud. 24 (2), 459, 2015.

6. DIXIT R., WASIULLAH, MALAVIYA D., PANDIYAN K., SINGH U.B., SAHU A., SHUKLA R., SINGH B.P., RAI J.P., SHARMA P.K., LADE H., PAUL D. Bioremediation of heavy metals from soil and aquatic environment: An overview of principles and criteria of fundamental processes. Sustainability. 7(2), 2189, 2015. https://doi.org/10.3390/su7022189

7. JIANG Y., CHAO S., LIU J., YANG Y., CHEN Y., ZHANG A., CAO H. Source apportionment and health risk assessment of heavy metals in soil for a township in Jiangsu Province, China. Chemosphere. 168, 1658, 2017. https://doi.org/10.1016/j.chemosphere.2016.11.088.

8. LOMBI E., HAMON R.E. Remediation of polluted soils. In: D. Hillel, Encyclopedia of Soils in the Environment, Elsevier, pp. 379-385, 2005. https://doi.org/10.1016/B0-12348530-4/00087-4.

9. LESTAN D. Remediation of toxic metal-contaminated soil using EDTA soil washing. In: Sherameti I., Varma A. (eds) Heavy Metal Contamination of Soils. Soil Biology, vol 44. Springer, Cham. 2015. https://doi. org/10.1007/978-3-319-14526-6 21

10. BLOEM E., HANEKLAUS S., HAENSCH R., SCHNUG E. EDTA application on agricultural soils affects microelement uptake of plants. Sci Total Environ. 577, 166, 2017. https://doi.org/10.1016/j.scitotenv.2016.10.153

11. LESTAN D.Novel chelant-based washing method for soil contaminated with $\mathrm{Pb}$ and other metals: A pilot-scale study. Land Degrad Develop. 28, 2585, 2017. https:/doi. org/10.1002/ldr.2818

12. WANG Y., ZHANG B., DENG T., LI, F.Reclamation of EDTA by sodium tetraethylenepentamine-multi dithiocarbamate after soil washing process with EDTA. Environ Earth Sci. 76, 311, 2017. https://doi.org/10.1007/ s12665-017-6587-8
13. LI Z., WU L., LUO Y., CHRISTIE P. Changes in metal mobility assessed by EDTA kinetic extraction in three polluted soils after repeated phytoremediation using a cadmium/zinc hyperaccumulator. Chemosphere. 194, 432, 2018. https://doi.org/10.1016/j.chemosphere.2017.12.005.

14. ABBAS M.H.H., ABDELHAFEZ A.A. Role of EDTA in arsenic mobilization and its uptake by maize grown on an As-polluted soil.Chemosphere. 90 (2), 588, 2013. https:// doi.org/10.1016/j.chemosphere.2012.08.042.

15. BEIYUAN J., TSANG D.C.W., VALIX M., BAEK K., OK Y.S., ZHANG W., BOLAN N.S., RINKLEBE J., LIX.D.Combined application of EDDS and EDTA for removal of potentially toxic elements under multiple soil washing schemes. Chemosphere. 205, 178, 2018. https:// doi.org/10.1016/j.chemosphere.2018.04.081

16. JEZ E., LESTAN D. 2016. EDTA retention and emissions from remediated soil. Chemosphere. 151, 202, 2016. https://doi.org/10.1016/j.chemosphere.2016.02.088

17. HU P., YANG B., DONG C., CHEN L., CAO X., ZHAO J., WU L., LUO Y., CHRISTIE P. Assessment of EDTA heap leaching of an agricultural soil highly contaminated with heavy metals. Chemosphere. 117, 532, 2014, https:// doi.org/10.1016/j.chemosphere.2014.08.081.

18. LIU Q., XU M., LI F., WU T., LI Y. Rapid and effective removal of $\mathrm{Cr}(\mathrm{VI})$ from aqueous solutions using the $\mathrm{FeCl} / \mathrm{NaBH} 4$ system. ChemEng J. 296, 340, 2016. https:// doi.org/10.1016/j.cej.2016.03.127.

19. LEE S.H., KWON O., YOO K., ALORRO R.D. Removal of $\mathrm{Zn}$ from contaminated sediment by $\mathrm{FeCl} 3$ in HClsolution. Metals. 5, 1812, 2015. https://doi.org/10.3390/met5041812

20. GUO X., WEI Z., WU Q., LI C., QIAN T., ZHENG W. Effect of soil washing with only chelators or combining with ferric chloride on soil heavy metal removal and phytoavailability: Field experiments. Chemosphere. 147, 412, 2016. https://doi.org/10.1016/j. chemosphere.2015.12.087.

21. CUI L., WANG Y., GAO L., HU L., YAN L., WEI Q., DU B. EDTA functionalized magnetic graphene oxide for removal of $\mathrm{Pb}(\mathrm{II}), \mathrm{Hg}(\mathrm{II})$ and $\mathrm{Cu}(\mathrm{II})$ in water treatment: Adsorption mechanism and separation property. ChemEng J. 281, 1, 2015. https://doi.org/10.1016/j.cej.2015.06.043.

22. ZOU Z., QIU R., ZHANG W., DONG H., ZHAO Z., ZHANG T., WEI X. CAI X. The study of operating variables in soil washing with EDTA. Environ Pollut. 157 (1), 229, 2009. https://doi.org/10.1016/j.envpol.2008.07.009

23. JONES J.B. Laboratory Guide for Conducting Soils Tests and Plant Analysis. CRC Press, Boca Raton, FL, USA. 2001.

24. YEROKUN O.A., CHIKUTA S., MAMBWE D. An evaluation of spectroscopic and loss on ignition methods for estimating soil organic carbon in Zambian soils. Int $\mathbf{J}$ Agri Res. 2, 965, 2007.

25. SABIENE N., BRAZAUSKIENE D.M., RIMMER D. Determination of heavy metals mobile forms by different extraction methods. EKOLOGIJA. 163, 1, 2004.

26. CAO X., MA L.Q., SINGH S.P., ZHOU Q. Phosphateinduced lead immobilization from different lead minerals in soils under varying $\mathrm{pH}$ conditions. Environ Pollut.152 (1), 184, 2008. https://doi.org/10.1016/j.envpol.2007.05.008.

27. LINDSAY W.L. Chemical equilibria in soils. The Blackburn Press, Cheshire. 2001.

28. NEVIDOMSKAYA D.G., MINKINA T.M., SOLDATOV A.V., SHUVAEVA V.A., ZUBAVICHUS Y.V., PODKOVYRINA Y.S. Comprehensive study of $\mathrm{Pb}$ (II) speciation in soil by X-ray absorption spectroscopy (XANES and EXAFS) and sequential fractionation. 
J Soils Sediments. 16, 1183, 2016. https://doi.org/10.1007/ s11368-015-1198-Z

29. HOUBEN D., EVRARD L., SONNET P. Mobility, bioavailability and $\mathrm{pH}$-dependent leaching of cadmium, zinc and lead in a contaminated soil amended with biochar. Chemosphere. 92 (11), 1450, 2013. https://doi. org/10.1016/j.chemosphere.2013.03.055.

30. WU L.H., LUO Y.M., CHRISTIE P., WONG M.H. Effects of EDTA and low molecular weight organic acids on soil solution properties of a heavy metal polluted soil. Chemosphere. 50 (6), 819, 2003. https://doi.org/10.1016/ S0045-6535(02)00225-4.

31. SUN B., ZHAO F.J., LOMBI E., MCGRATH S.P. Leaching of heavy metals from contaminated soils using EDTA. Environ Pollut. 113 (2), 111, 2001. https://doi. org/10.1016/S0269-7491(00)00176-7.

32. CONTIN M., MALEV O., IZOSIMOVA A., DE NOBILI M. Flocculation of sewage sludge with $\mathrm{FeCl}_{3}$ modifies the bioavailability of potentially toxic elements when added to different soils. Ecol Eng. 81, 278, 2015. https://doi. org/10.1016/j.ecoleng.2015.04.033.

33. HUANG Y., KELLER A.A. EDTA functionalized magnetic nanoparticle sorbents for cadmium and lead contaminated water treatment. Water Res. 80, 159, 2015. https://doi.org/10.1016/j.watres.2015.05.011.

34. GU Y., YEUNG A.T., LI H. Enhanced electrokinetic remediation of cadmium-contaminated natural clay using organophosphonates in comparison with EDTA. Chin J Chem Eng. 26 (5), 1152, 2018. https://doi.org/10.1016/j. cjche.2017.10.012.

35. HAN Y., ZHANG L., GU J., ZHAO J., FU J. Citric acid and EDTA on the growth, photosynthetic properties and heavy metal accumulation of Iris halophila Pall. cultivated in $\mathrm{Pb}$ mine tailings. IntBiodeterior Biodegradation. 128, 15, 2018. https://doi.org/10.1016/j.ibiod.2016.05.011.

36. WEI M., CHEN J., WANG X. Removal of arsenic and cadmium with sequential soil washing techniques using
Na2EDTA, oxalic and phosphoric acid: Optimization conditions, removal effectiveness and ecological risks. Chemosphere. 156, 252, 2016. https://doi.org/10.1016/j. chemosphere.2016.04.106.

37. LIN Z., ZHANG R., HUANG S., WANG K. Impact of chemical leaching on permeability and cadmium removal from fine-grained soils. Environ SciPollutRes. 24, 18229, 2017. https://doi.org/10.1007/s11356-017-9523-2

38. MAKINO T., SUGAHARA K., SAKURAI Y., TAKANO H., KAMIYA T., SASAKI T., ITOU T., SEKIYA N. Remediation of cadmium contamination in paddy soils by washing with chemicals: Selection of washing chemicals. Environ Pollut. 144 (1), 2, 2006.https://doi.org/10.1016/j. envpol.2006.01.017.

39. LAI H.Y., LIN Y.C., WANG Y.S., FU B.W. Removal of cadmium from contaminated soils by multiple washing with iron (III) chloride. Soil Sediment Contam. 25 (6), 624, 2016. https://doi.org/10.1080/15320383.2016.1190312

40. LI J.S., XUE Q., WANG P., ZHANG T.T. Enhanced washing for $\mathrm{Cr}(\mathrm{VI})$ removal from contaminated soil using EDTA and microwave radiation. Environ Earth Sci. 74, 2167, 2015. https://doi.org/10.1007/s12665-015-4206-0

41. GITIPOUR S., AHMADI S., MADADIAN E., ARDESTANI M. Soil washing of chromium- and cadmium-contaminated sludge using acids and ethylenediaminetetra acetic acid chelating agent. Environ Technol. 37 (1), 145, 2016. https://doi.org/10.1080/0959333 0.2011 .597784

42. ABUMAIZAR R.J., SMITH E.H. Heavy metal contaminants removal by soil washing.J Hazard Mater. 70 (1-2), 71, 1999. https://doi.org/10.1016/S03043894(99)00149-1.

43. REIJONEN I., HARTIKAINEN H. Oxidation mechanisms and chemical bioavailability of chromium in agricultural soil $-\mathrm{pH}$ as the master variable. Appl Geochem. 74, 84, 2016. https://doi.org/10.1016/j.apgeochem.2016.08.017. 